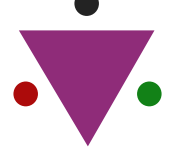

IJCRR

Section: Healthcare

Sci. Journal Impact

Factor: $6.1(2018)$

ICV: 90.90 (2018)

(c) (i) (3)

Copyright@IJCRR

\section{Correlation between Height and Foot Length in Saudi Population in Majmaah, Saudi Arabia}

\section{Ghaffar UB ${ }^{1}$, Riyaz Ahamed Shaik², Ali Farazํ, Waqas Sami², Sajid Hussain², Nazia Khan ${ }^{1}$}

'Department of Pathology, College of Medicine, Majmaah University, Al-Majmaah 11952, Saudi Arabia; ${ }^{2}$ Department of Community Medicine and Public Health, Majmaah University, Al-Majmaah 11952, Saudi Arabia; ${ }^{3}$ Department of Basic Sciences, College of Medicine, Majmaah University, Al-Majmaah 11952, Saudi Arabia.

\title{
ABSTRACT
}

Background: Stature is one of the most important elements in the identification of an individual. Assessing hand and foot dimensions for height estimation has always been of immense interest to the anatomist, scientist and forensic experts. The present study was carried out to determine the height from the foot length in the population of Saudi Arabia.

Method: This observational cross-sectional study was conducted among male and female students aged 18-25 years studying at College of Medicine, Majmaah University, Kingdom of Saudi Arabia, having no foot deformity, spinal or bony injuries or surgeries. The obtained data were statistically analyzed.

Results: The mean Stature $(\mathrm{cm})$ of the male was 173.19 \pm 5.29 , Left Foot length $(\mathrm{cm})$ was $26.0 \pm 1.40)$ and Right Foot length (cm) was (26.0 \pm 1.52$)$. While the mean stature $(\mathrm{cm})$ of female was $158.56 \pm 5.55$, Left Foot length $(\mathrm{cm})$ was $23.19 \pm 1.14$ and Right Foot length $(\mathrm{cm})$ was23.19 \pm 1.16 . Males having significantly higher values than females. Correlation by comparing the Pearson correlation coefficient and foot length ( $F L)$ showed the relationship in males $(r=0.602, p<0.01)$ and females $(r=0.629$, $p<0.01)$.

Conclusion: It can be concluded from the study that males have a greater mean value of stature when compared to females. It was observed that there is the existence of a direct relationship between the foot length with the stature in both the sexes.

Key Words: Stature, Foot length, Height, Gender

\section{INTRODUCTION}

The system of identifying criminals based upon the anthropometric measurement prevailed as a strategic technique in 1882 in the field of forensics. ${ }^{1}$ Since then it has been widely applied as an effective tool for forensic identification but unfortunately, very less attention has been conferred to the study of the human feet and footprints in this field., ${ }^{2,3}$ In the year 1968, Rutishauser first demonstrated that the reliability of height prediction from the foot length in humans was significantly higher than from the long bones. ${ }^{4}$ Identification of the human beings for legal or humanitarian reasons are performed by various methods in which the stature constitutes a vital element particularly in those involving mutilated, decomposed or amputated body fragments due to catastrophic events like bomb blasts, earthquakes, terror attacks, mass accidents etc. thereby proving that the foot and its segments are highly significant for the personal identification in the cases of mass disasters. ${ }^{5,6}$
One of the forensic investigations for identification of an individual in the study of Anthropometry. Various parameters used for identification are the determination of age, sex, race etc. The determination of stature of an individual from skeleton material or the mutilated or amputated limbs or parts of limbs has obvious signs in the personal identification in the events of murders, accidents or natural disasters as required in forensic identification analysis.

Studies employing hand and foot dimensions for height estimation has been reported by several countries like India ${ }^{7-9}$, Egypt $^{10}$, Mauritius ${ }^{11,12}$, Nigeria ${ }^{13,14}$, Sri Lanka ${ }^{15}$, Turkey ${ }^{7,9}$ and the United States of America. ${ }^{18}$ The foot size along with the other anatomical structures of the body like the head, trunk and the lengths of upper and lower limbs is assumed to influence a definitive biological correlation with the stature. Rarely, there have been no studies done using similar parameters in Saudi Arabia and it was felt that dire requirement for the assessment of the relationship between the foot length as well as body

\section{Corresponding Author:}

Dr. U. B. Ghaffar, Assistant Professor, Department of Pathology, College of Medicine, Majmaah University, Al-Majmaah 11952, Saudi Arabia; Contact: +966507457418; Email: ubghaffar@gmail.com

ISSN: 2231-2196 (Print)

Received: 25.07.2020
ISSN: $0975-5241$ (Online)

Revised: 19.09 .2020
Accepted: 21.10 .2020
Published: 12.11 .2020 
height for gauging the ethnic peculiarity among this specified population. This study would also assist in the development of a regression equation for the estimation of the stature from foot length based on its correlation with each other.

\section{MATERIALS AND METHODS}

This observational cross-sectional study was conducted among the male and female students studying at the College of Medicine, Majmaah University, Kingdom of Saudi Arabia. The age group of the sample population was in the range of $18-25$ years. The period of the study was 4 months allotted from $1 / 12 / 2018$ to $31 / 03 / 2019$. The data was collected from a sample population of 133 students employing complete enumeration probability sampling method. The exclusion criteria for the participants enrolled in this study were: - 1) pedal deformity or injury, 2) spinal abnormalities, 3) abnormal heights like gigantism, dwarfism etc., and 4) age less than 18 years. Institutional Ethical Committee approval was obtained for the study. Data collected comprised of the height of the individual (in $\mathrm{cm}$ ) and the foot length (in $\mathrm{cm}$ ).

All subjects examined for: -

Height measurement: The body height was measured using an anthropometer/Stadiometer. Participants were made to stand barefoot in the anatomical position and height was measured from vertex to floor in centimetres.

Foot length: The subjects were made to place their foot on a white plane sheet and the foot outline was then drawn with a sharp-pointed pencil and the anatomical landmarks of the foot. The measurement of foot length was recorded in centimetres from the most prominent point on the back of the heel to tip of great toe or second toe tip.

\section{Statistical Analysis}

The data was recorded and then analyzed using IBM SPSS 25.0. Mean + SD were calculated for normally distributed quantitative variables. The normality of the data was analyzed through the one-sample Kolmogorov - Smirnov test. The person correlation was calculated to study the relationship between stature and the length of feet. Simple linear regression analysis was performed on a different set of the variables for studying the relationship predictions. A p-value of $<0.05$ was considered a statistically significant value.

\section{Ethical Approval}

All procedures performed in this study using human participants were done in accordance to the ethical standards of the institutional with the 1964 Helsinki declaration and its later amendments or comparable ethical standards. IRB approval was obtained from the ethical committee with the approval No. 16930/06.

\section{RESULTS}

In the present study as shown in Table 1 the mean stature of the male was $173.19 \mathrm{~cm}$ and in female was $158.5 \mathrm{~cm}$. The mean left foot length was $26.0 \mathrm{~cm}$ in male and $23.19 \mathrm{~cm}$ in female and right foot length was found to be $26.0 \mathrm{~cm}$ in male and $23.19 \mathrm{~cm}$ in the female. Mean foot length of the male was found to be larger than the female.

In our study in Table 2, there is a strong significant relationship $(r=0.602, p<0.01)$ between male foot length and body stature. A similar correlation was seen in female stature and foot length $(\mathrm{r}=0.629, \mathrm{p}<0.01)$. In our study, the regression coefficient (b) height \& foot length in male was 2.13 and in female 2.96 .

Table 3 in our study represents the regression equation for the estimation of stature from the measurements of feet in both the sexes. Worldwide, the regression formulas are accepted as one of the most important components for the determination of stature from various anthropometric dimensions. A computer analysis of the data enabled the calculation of regression coefficients ' $a$ ' and ' $b$ ', where ' $a$ ' is the regression coefficient of the dependent variable i.e. stature and ' $b$ ' is the regression coefficient of the independent variable i.e. foot length. Hence, stature $=\mathrm{a}+$ box; where $\mathrm{x}=$ measurement of foot length. The SEE predicts the deviations of estimated stature from the actual stature. It was found to be between \pm 4.22 for males and \pm 4.41 for females. The correlation coefficient (r) and the coefficient of determination (R2) were calculated to be best for females than males.

\section{DISCUSSION}

The stature of an individual serves as an inherent characteristic that varies according to the race and ethnicity.19 Ossification and maturation occur earlier in the foot than in the long bones and therefore the stature could be more precisely determined in the adolescence age from foot measurement as compared to that from the long bones. ${ }^{20}$

The difference in these measurements(Table-1) were found to be statistically significant in both the sexes and the findings were similar to previous studies. ${ }^{21,22}$ Rameswarapu Babu et al in their study on height with foot length showed height in male and female participants recorded were 154 to $182 \mathrm{~cm}$ and 140 to $174 \mathrm{~cm}$ respectively with a significant correlation between them. Left foot length from $23-27 \mathrm{~cm}$ in male and 21 to $27 \mathrm{~cm}$ in female and right foot length from $22-27 \mathrm{~cm}$ in male and 21 to $27 \mathrm{~cm}$ in the female. It shows the positive correlation coefficients between parameters which were significant indicating that the foot length provides high reliability and accuracy in estimating stature of an unknown individual..$^{23}$ In the Gujarat region (India) in the age group of 14 to 25 years and they concluded that a fairly good estimation of the height can be made using regression equations in either 
sex. ${ }^{20}$ A study on humans and developed a regression equation capable of calculating the height of an individual from his foot length and revealed that as the height increased, foot length of both male and female also increased. ${ }^{24}$ Cameras et al. reported the correlation between foot breadth and foot length with 0.42 and 0.70 in males and 0.69 and 0.70 for females. ${ }^{25}$ The previous study on the population of Turkey proved that the mean height in male was $172.4 \mathrm{cms}$ and in female was $162.0 \mathrm{cms}$. The foot length in male was $25.0 \mathrm{cms}$ and female was $22.8 \mathrm{cms}$. The correlation coefficient(r) for a male is 0.696 and female was 0.496 which was significant. ${ }^{26}$

In a Slovakian population study was done and found that the mean height in male was $180 \mathrm{cms}$ and in female was 168.3 cms. The foot length in male is $37.9 \mathrm{cms}$ and female is 38.4 $\mathrm{cms}$. The correlation coefficient ( $\mathrm{r}$ ) for male was 0.759 and for female was 0.722 which was considered significant ${ }^{27}$. Sanli et al.16established the relationship between hand length, foot length and stature using multiple linear regression analyses. Their study sample included 155 adults ( 80 male, 75 female) Turks residing in Adana. They found multiple linear regression model for both genders together being the better model with multiple correlation coefficient $\mathrm{R}$ to be 0.928 .

Thus, the accuracy of stature estimation is higher in the case of females with similarities to the study by Krishan and Sharma. The different regression equations derived from different studies revealed that these formulae can be applied only to the population from which the data has been collected due to the inherent population variation in these dimensions, which can be attributed to the influence by genetic and environmental factors like the nutrition, climate etc.

The different regression equations of different studies showed that these formulae apply only to the population from which the data has been collected, due to inherent population variation in these dimensions, which may be attributed to genetic and environmental factor like climate, nutrition etc. Sen and Ghosh recommended that it would be unwise to use the same equations for stature estimation in different population groups ${ }^{28}$. Therefore depending upon the availability of the body parts, stature may be estimated using linear regression equations with reasonable accuracy. Moreover, these regression equations are also different in males and females because of the difference in gender stature and foot length as both parameters have higher values in males so necessitating the different regression equations for both genders. The ideal study to formulate regression equation for all population should be community-based. Moreover, these equations cannot be applied for giants and dwarfs.

\section{CONCLUSION}

This research was focused on the determination of the stature and foot length of the Saudi Arabian population and to derive a correlative equation that could enable the prediction of stature using the foot length among the adult individuals. This study, therefore, suggests that the foot length could serve as potential parameters for the determination of stature among various other ethnic groups. Hence there is a requirement for conducting more studies among the people of different regions and ethnicity so that stature measurement becomes established as a more reliable parameter for identification of an individual.

\section{ACKNOWLEDGMENT}

The author would like to thank Deanship of Scientific Research of Majmaah University for supporting this work under Project Number 16930/06.

\section{Conflict of interest}

The authors declare that there was no conflict of interest.

Funding: This research received no external funding.

\section{REFERENCES}

1. Waghmare V, Gaikwad R, Herekar NG. Estimation of the stature from the anthropometric measurement of hand length. Internet $\mathrm{J}$ Bio Anthropol 2011;4(2):1-5.

2. Zeybek G, Ergur I, Demiroglu Z. Stature and gender estimation using foot measurements. Forensic Sci Int 2008; 181(1-3): 54e1-5.

3. Jakhar JK, Pal V, Paliwal PK. Estimation of height from measurements of foot length in Haryana region. J Ind Aca Forensic Med 2010; 32(3): 231-233.

4. Rutishauser IH. Prediction of height from foot length: Use of measurement in field surveys. Arch Dis Childhood 1968; 43(229):310.

5. Geissmann T. Estimation of Australopithecine stature from long bones: AL 288-1 as a test case. Folia Primatologica 1986; 47(23): 119-127.

6. Chikhalkar BG, Mangaonkar AA, Nanandkar SD, Peddawad RG. Estimation of stature from lntact long limb Bones. J Ind Acad Forensic Med 2010; 32(4): 329-321.

7. Sharma VK, Garg RK, Chattopadhyay PK. Calculation of stature from foot measurements: a study of Gaur Brahmins. Coll Antropol 1978; 2: 194-195.

8. Nath S. Estimation of stature through hand and foot lengths among Jats of Rajasthan. Police Res Dev J 1997; 20-2.

9. Nath S. Reconstruction of stature from percutaneous measurements of upper and lower extremity segments among Punjabi females of Delhi. Ind J Forensic Sci 1990; 4: 171-181.

10. Abdel-Malek AK, Ahmed AM, El Sharkawi SA, El NA. Prediction of stature from hand measurements. Forensic Sci Int 1990; 46(3): 181-187.

11. Agnihotri AK, Agnihotri S, Jeebun N, Googoolye K. Prediction of stature using hand dimensions. J Forensic Legal Med 2008; 15(8): 479-482.

12. Agnihotri AK, Agnihotri S, Jeebun N, Googoolye K. Prediction of stature using hand dimensions. J Forensic Legal Med 2008; 15(8): 479-482.

13. Agnihotri AK, Purwar B, Googoolye K, Agnihotri S, Jeebun N. Estimation of stature by foot length J Forensic Legal Med 2007; 
14(5): 279-83.

14. Bob-Manuel IF, Didia BC. Sexual dimorphism in foot dimensions among adult Nigerians. Internet J Biol Anthropol 2009; 3(1):1-6.

15. Ibeachu PC, Abu EC, Didia BC. Anthropometric sexual dimorphism of hand length, breadth and hand indices of University of Port-Harcourt students. Asian J Med Sci 2011; 3(4): 146-150.

16. Ilayperuma I, Nanayakkara G, Palahepitiya N. Prediction of personal stature based on the hand length. Galle Medical Journal, 14(1):15-18.

17. Sanli SG, Kizilkanat ED, Boyan N, Ozsahin ET, Bozkir MG, Soames R, Erol H, Oguz O. Stature estimation based on hand length and foot length. Clinical Anatomy. Clin Anat 2005; 18(8): 589-596.

18. Giles E, Vallandigham PH. Height estimation from foot and shoeprint length. J Forensic Sci 1991; 36(4): 1134-1151.

19. Rastogi P, Nagesh KR, Yoganarasimha K. Estimation of stature from hand dimensions of north and south Indians. Legal Med 2008; 10(4): 185-189.

20. Patel SM, Shah GV, Patel SV. Estimation of height from measurements of foot length in Gujarat region. J Anat Soc India 2007; 56(1): 25-27.

21. Krishan K, Sharma A. Estimation of stature from dimensions of hands and feet in a North Indian population. J Forensic Legal Med 2007; 14(6): 327-332.
22. Ozden H, Balci Y, Demirüstü C, Turgut A, Ertugrul M. Stature and sex estimate using foot and shoe dimensions. Forensic Sci Int 2005; 147(2-3): 181-184.

23. Agarwal P, Singh A, Gupta R. Estimation of human stature by measurements of foot. National J Integr Res Med 2018; 9(5).

24. Mohanty BB, Agrawal D, Mishra K, Samantsinghar P, Chinara PK. Estimation of the height of an individual from foot length: a study on the population of Odisha. Int J Rev Sci 2012; 2: 69-74.

25. Qamra SR, Jit I, Deodhar SD. A model for the reconstruction of height from foot measurements in an adult population of NorthWest India. Ind J Med Res 1980; 71: 77-83.

26. Ozaslan A, Karadayi B, Kolusayin MO, Kaya A, Afsin H. Predictive role of hand and foot dimensions in stature estimation. Rom J Leg Med 2012; 20(1): 41-46.

27. Uhrova P, Benus R, Masnicova S, Obertova Z, Kramarova D, Kyselicova K, Dornhoferova M, Bodorikova S, Nessakova E. Estimation of stature using hand and foot dimensions in Slovak adults. Legal Medicine 2015; 17(2): 92-97.

28. Sen J, Ghosh S. Estimation of stature from foot length and foot breadth among the Rajbanshi: an indigenous population of North Bengal. Forensic Sci Int 2008; 181(1-3): 55-e1.

Table 1: Anthropometric measurements of the subject

\begin{tabular}{lccc} 
Subject & $\begin{array}{c}\text { Body height range cms } \\
(\text { mean } \pm \text { SD })\end{array}$ & $\begin{array}{c}\text { Left Foot length range cms } \\
(\text { mean } \pm \text { SD })\end{array}$ & $\begin{array}{c}\text { Right Foot length range cms } \\
(\text { mean } \pm \text { SD })\end{array}$ \\
Male & $161-184$ & $20.5-29.0$ & $19.50-29.0$ \\
& $(173.19 \pm 5.29)$ & $(26.0 \pm 1.40)$ & $(26.0 \pm 1.52)$ \\
Female & $147-168$ & $21-26$ & $20.6-26.3$ \\
& $(158.56 \pm 5.55)$ & $(23.19 \pm 1.14)$ & $(23.19 \pm 1.16)$ \\
Both Gender & $147-184$ & $20.5-29.0$ & $19.5-29.0$ \\
& $(168.35 \pm 8.74)$ & $(25.0 \pm 1.9)$ & $(25.0 \pm 1.94)$ \\
\hline
\end{tabular}

Table 2: Descriptive statistics of parameters in both male and female

\begin{tabular}{lccc} 
Parameter & Male & Female & Both \\
Correlation coefficient ( $r$ ) height \& foot lenght & 0.602 & 0.629 & 0.812 \\
Regression coefficient (b) Height \& foot length & 2.13 & 2.96 & 3.72 \\
Value of contant (a) height \& foot length & 117.7 & 89.90 & 75.29 \\
\hline
\end{tabular}

Table 3: Linear regression formula for body height $(\mathrm{cm})$ from foot length

\begin{tabular}{|c|c|c|c|c|c|}
\hline Sex & Regression equation & S.E.E & $\begin{array}{l}\text { Co-efficient of determination } \\
\left(\mathbf{R}_{\mathbf{2}}\right)\end{array}$ & Adjusted ( $\left.\mathbf{R}_{\mathbf{2}}\right)$ & P-value \\
\hline Male & $\mathrm{BH}=117.75+2.13^{*} \mathrm{FL}$ & 4.27 & 0.363 & 0.348 & 0.049 \\
\hline Female & $\mathrm{BH}=89.90+2.96^{*} \mathrm{FL}$ & 4.41 & 0.397 & 0.367 & 0.045 \\
\hline Both & $\mathrm{BH}=75.29+3.72 * \mathrm{FL}$ & 4.48 & 0.379 & 0.356 & 0.023 \\
\hline
\end{tabular}

BH-Body height; FL-Foot length 